\title{
SUMBERDAYA MANUSIA BERKUALITAS DALAM UPAYA PENINGKATAN DAYA SAING INDUSTRI KELAPA SAWIT DI KABUPATEN KETAPANG
}

\author{
Tardi Kurniawan" $^{1 *}$, Anto Susanto1), Assrorudin'), Refid Ruhibnur ${ }^{2}$. \\ ${ }^{1)}$ Staf Pengajar di Jurusan Pengelolaan Hasil Perkebunan, Politeknik Negeri Ketapang \\ ${ }^{2)}$ Staf Pengajar di Jurusan Teknik Informatika, Politeknik Negeri Ketapang \\ Jln. Rangga Sentap-Dalong, Kelurahan Sukaharja, Kecamatan Delta Pawan, Kabupaten Ketapang, \\ Kalimantan Barat 78813. Indonesia \\ tardikurniawan@plitap.ac.id
}

\begin{abstract}
Assessing the readiness of human resources in Ketapang Regency in supporting the development and improvement of the competitiveness of the palm oil industry in the face of the MEA free-market competition, research is needed. This research involved economic actors or oil palm industry entrepreneurs in Ketapang Regency and also related local government institutions as respondents. Completeness of data and information in this study was also obtained from secondary data sources in the form of official local government documents both at the provincial level of West Kalimantan and the level of the Government of Ketapang Regency. The research method used is descriptive research, namely research that is more directed at disclosing problems or circumstances as they are and reveals the facts that are equipped with interpretations or analyzes of the industry of oil palm plantations, especially those in Ketapang Regency. The results of the study found that the human resources needed to support the development and improvement of the oil palm industry in Ketapang Regency in the face of free-market competition MEA are human resources that not only have the ability of education, expertise and productivity but must be equipped with foreign language proficiency skills, such as language English. Whereas the business strategies and policies that need to be implemented by the oil palm industry in Ketapang Regency in the face of MEA free-market competition are: (1) rapid growth or reduction strategies, (2) product mix change strategies, (3) market reach change strategies (4) repositioning strategies, (5) diversification strategies, and (6) partnering strategies.
\end{abstract}

Keywords: MEA, human resources, business strategy, and policy.

\begin{abstract}
ABSTRAK
Mengkaji kesiapan sumberdaya manusia di Kabupaten Ketapang dalam mendukung pengembangan dan peningkatan daya saing industri kelapa sawit menghadapi persaingan pasar bebas MEA maka perlu dilakukan penelitian. Penelitian ini melibatkan pelaku ekonomi atau pengusaha industri kelapa sawit yang ada di Kabupaten Ketapang dan juga institusi pemerintah daerah terkait sebagai responden. Kelengkapan data dan informasi dalam penelitian ini juga diperoleh dari sumber data sekunder berupa dokumen resmi pemerintah daerah baik di tingkat Provinsi Kalimantan Barat maupun tingkat Pemerintah Kabupaten Ketapang. Metode penelitian yang digunakan adalah penelitian deskriptif, yaitu penelitian yang lebih mengarah pada pengungkapan masalah-masalah atau keadaan sebagaimana adanya dan mengungkapkan fakta-fakta yang ada dilengkapi dengan interpretasi atau analisis tentang industri perkebunan kelapa sawit, khususnya yang ada di Kabupaten Ketapang. Hasil penelitian menemukan bahwa sumberdaya manusia yang dibutuhkan untuk mendukung pengembangan dan peningkatan industri kelapa sawit di Kabupaten Ketapang dalam menghadapi persaingan pasar bebas MEA adalah
\end{abstract}


sumberdaya manusia yang tidak hanya memiliki kemampuan pendidikan, keahlian, dan produktivitas namun harus dibekali dengan kemampuan penguasaan bahasa asing, seperti bahasa Inggris. Sedangkan strategi dan kebijakan bisnis yang perlu diterapkan oleh industri kelapa sawit di Kabupaten Ketapang dalam menghadapi persaingan pasar bebas MEA adalah: (1) strategi pertumbuhan yang cepat atau pengurangan, (2) strategi perubahan bauran produk, (3) strategi perubahan jangkauan pasar, (4) strategi repositioning, (5) strategi diversifikasi, dan (6) strategi partnering.

\section{Kata kunci: MEA, sumberdaya manusia, strategi dan kebijakan bisnis.}

\section{PENDAHULUAN}

Peningkatan luas lahan perkebunan elapa sawit berdampak pada peningkatan produksi minyak kelapa sawit Indonesia sehingga menjadikan Indonesia sebagai produsen minyak kelapa sawit terbesar di dunia dalam beberapa tahun terakhir. Konsumsi minyak sawit dunia cenderung terus meningkat selama kurun waktu lima tahun terakhir yakni: tahun 2005 sebesar 183.6 juta ton, tahun 2010 sebesar 216.2 juta ton, tahun 2015 sebesar 243.9 juta ton, tahun 2020 sebesar 285.8 juta ton, dan tahun 2025 sebesar 318.7 juta ton atau rata-rata pertumbuhan dalam kurun waktu 2010-2025 sebesar 2.8\%. Hal ini menunjukkan bahwa konsumsi minyak nabati dunia cenderung terus meningkat, terutama di Negara-negara Cina, India, dan Brazil. Oleh karena itu dapat dinyatakan bahwa berdasarkan pada kenyataan ini pasar minyak nabati dunia sangat prospektif, dimana minyak kelapa sawit memiliki pangsa produksi terbesar mencapai 124.5 juta ton pada tahun 2013, demikian pula dengan total konsumsi minyak dunia terbesar mencapai 57.4 juta ton atau hampir separuh kebutuhan minyak nabati dunia dipasok oleh minyak kelapa sawit.

Industri kelapa sawit sangat pesat, dan berbagai macam produk telah dihasilkan, demikian halnya hasil riset yang dilakukan, Food grade grase berbasis minyal sawit crude palm oil (Susanto, A dan Akhdiyatul, 2017), Perlakuan konsentrasi bahan kimia pengental/thickening agent (LiOH) pada minyak CPO dalam pembuatan Food Grade Grase (Totok, M., A. Susanto., dan I. Pratiwi, 2017), hingga penelitian pemanfatan limbah dari industri sawit, seperti pembuatan briket bioarang cangkang dan tankos sawit (Susanto, A. dan T. Yanto, 2013), serta sampai pada pemanfaatan limbah tandan kosong kelapa sawit, abu boiler dan limbah cair pabrik kelapa sawit untuk perbaikan sifat tanah gambut (Rosmalinda, 2017). Sehingga, hasil riset tersebut memberikan andil dalam peningkatan konsumsi minyak kelapa sawit yang direspon dengan dilakukannya peningkatan luas lahan perkebunan kelapa sawit, dan akan memunculkan konsekuensi penyediaan sumberdaya manusia sebagai tenaga kerja dalam jumlah yang sangat banyak yakni mencapai hamper empat juta orang. Sumber pemasok tenaga 
kerja ini tidak hanya berasal dari Indonesia tetapi dapat berasal dari Negara lain terutama di kawasan ASEAN sehubungan dengan diberlakukannya Masyarakat Ekonomi ASEAN (MEA) yang dimulai pada tahun 2015. Dalam suasana pasar bebas MEA maka beraneka jenis produk berupa barang dan jasa termasuk investasi dan tenaga kerja dapat masuk secara bebas di wilayah negera-negara ASEAN termasuk ke Indonesia. Provinsi Kalimantan Barat sebagai bagian dari wilayah Indonesia akan terkena dampak masuknya tenaga kerja asing yang berasal dari Negara-negara ASEAN untuk bekerja di industri kelapa sawit. Demikian pula dengan Kabupaten Ketapang yang termasuk wilayah 3T (terdepan, tertinggal, dan terluar), dimana terbuka akses yang sangat mudah bagi tenaga kerja asing untuk memasuki wilayah Kabupaten Ketapang dan bekerja di industri perkebunan kelapa sawit yang ada di wilayah kabupaten ini.

Salah satu tindakan antisipatif dalam menghadapi persaingan pasar bebas MEA, khususnya pada sektor industri perkebunan kelapa sawit di Kabupaten Ketapang adalah dengan menyiapkan sumberdaya manusia berkualitas yang memiliki kompetensi akademik, sosial, dan professional terutama yang berkaitan dengan bidang keahlian industri kelapa sawit mulai dari industri hulu sampai industri hilir. Profil sumberdaya manusia seperti apa yang dibutuhkan dalam pengembangan dan peningkatan industri perkebunan kelapa sawit di Kabupaten Ketapang menghadapi pasar bebas MEA menjadi menarik untuk dikaji dalam penelitian ini. Penelitian ini bertujuan untuk mengidentifikasi profil sumberdaya manusia yang dibutuhkan untuk mendukung pengembangan dan peningkatan industri kelapa sawit di Kabupaten Ketapang dalam menghadapi persaingan pasar bebas MEA; dan Merumuskan strategi dan kebijakan bisnis yang perlu diterapkan oleh industri perkebunan kelapa sawit di Kabupaten Ketapang dalam menghadapi persaingan pasar bebas MEA.

\section{METODOLOGI}

Penelitian ini merupakan penelitian deskriptif, yaitu penelitian yang lebih mengarah pada pengungkapan suatu masalah atau keadaan sebagaimana adanya dan mengungkapkan faktafakta. Yang menjadi subjek dalam penelitian ini adalah industri kelapa sawit di Kabupaten Ketapang Provinsi Kalimantan Barat. Variabel penelitian adalah objek penelitian atau apa yang menjadi titik perhatian dalam suatu penelitian. Yang dijadikan variable dalam penelitian ini adalah faktor-faktor daya saing dan sumberdaya manusia industry kelapa sawit Kabupaten Ketapang dalam menghadapi MEA. Pengumpulan data dalam penelitian ini menggunakan teknik sebagai berikut: Observasi, wawancara, kuesioner, dan Dokumentasi. Teknik analisis 
data yang digunakan dalam penelitian ini adalah analisis deskriptif, yaitu analisis dengan menggambarkan keadaan di lapangan kemudian membandingkan dengan teori-teori yang ada.

\section{PEMBAHASAN}

\subsection{Gambaran Umum Ketapang}

Kabupaten Ketapang merupakan kabupaten terluas dibanding 14 kabupaten/kota lain di Provinsi Kalimantan Barat yaitu sebesar $31.588 \mathrm{~km} 2$ atau sekitar 21,28 persennya luas total Kalimantan Barat yang sebesar 146.807 km2. Secara geografis, Kabupaten Ketapang berada pada posisi 0019' 26,51' 'Lintang Selatan (LS) sampai dengan 30 4'16,59', Lintang Selatan (LS) dan 1090 47’36,55', Bujur Timur (BT) sampai dengan 1110 21'37,36' Bujur Timur (BT), dan posisinya paling selatan di Provinsi Kalimantan Barat (Ketapang dalam angka, 2015).

Diantara 14 Kabupaten/Kota di Provinsi Kalimantan Barat, Kabupaten Ketapang adalah Kabupaten dengan wilayah terluas yaitu 31.240,74 Km2 atau 21,28 persen dari seluruh luas wilayah Propinsi Kalimantan Barat. Sedangkan jumlah penduduk Kabupaten Ketapang hanya 9,94 persen dari jumlah penduduk Provinsi Kalimantan Barat (Ketapang dalam angka, 2015).

Berdasarkan hasil proyeksi penduduk tahun 2015 jumlah penduduk Kabupaten Ketapang diprediksi sebanyak 475.985 jiwa (246.227 jiwa berjenis kelamin laki-laki dan 229.222 jiwa berjenis kelamin perempuan). Komposisi penduduk adalah pengelompokkan penduduk berdasarkan kriteria (ukuran) tertentu. Dasar untuk menyusun komposisi penduduk yang umum digunakan adalah jenis kelamin, kelompok umur, tingkat pendidikan, agama, tempat tinggal, dan pekerjaan.Pengelompokkan penduduk dapat digunakan untuk dasar dalam pengambilan kebijakan dan pembuatan program dalam mengatasi masalah-masalah di bidang kependudukan (Ketapang dalam angka, 2015).

Tingkat Partisipasi Angkatan Kerja (TPAK) tahun 2015 lebih rendah dibandingkan dengan tahun 2014, yaitu dari 70,95 persen menjadi 67,83 persen. Peningkatan TPAK ini diikuti dengan peningkatan Tingkat Pengamgguran Terbuka (TPT), yakni sebesar 2,06 persen di tahun 2014 menjadi 4,29 persen. Pada tahun 2015 terdapat 228.013 penduduk yang termasuk angkatan kerja, sekitar 95,70 persen bekerja dan sisanya sekitar 4,30 persen berstatus pengangguran (Dinas Perkebunan, 2015).

Pertumbuhan ekonomi Kabupaten Ketapang adalah sekitar 5,53 persen pada tahun 2015. Keadaan pertumbuhan ekonomi tersebut mengalami peningkatan jika dibandingkan dengan 
tahun 2014. Terdapat tiga kategori lapangan usaha yang paling tinggi tingkat pertumbuhannya yaitu; kategori konstruksi sekitar 12,90 persen, kategori perdagangan besar dan eceran, reparasi mobil dan sepeda motor sekitar 12,36 persen, dan kategori penyediaan akomodasi dan makan minum sekitar 10,95 persen. Pertumbuhan ekonomi tersebut lebih tinggi jika dibanding kan dengan rata-rata pertumbuhan ekonomi Provinsi Kalimantan Barat yang sebesar 4,81 persen.

Pada tahun 2015 di Kabupaten Ketapang terdapat 737 unit usaha industri kecil menengah, jumlah tersebut lebih banyak dibanding tahun 2014. Industri kecil menengah di Kabupaten Ketapang menyerap sebanyak 4.663 orang tenaga kerja dan didominasi oleh pekerja laki-laki. Nilai investasi industri kecil menengah tahun 2015 adalah sebesar 38,90 milyar rupiah, lebih banyak dibandingkan dengan nilai nominal investasi tahun 2014. Daerah perkotaan Kecamatan Delta Pawan dan Kecamatan Benua Kayong menjadi lokasi utama industri kecil menengah. Selain itu terdapat 21 unit industri besar yang berstatus aktif di Kabupaten Ketapang pada tahun 2014, dan menyerap sebanyak 1.492 pekerja (Dinas Perkebunan, 2015)

\subsection{Industri Kelapa Sawit di Ketapang}

Sekitar 98,99 persen hasil perkebunan Kabupaten Ketapang pada tahun 2013 merupakan andil komoditas tanaman kelapa sawit.

Tabel 1. Rekapitulasi Luas dan Produksi Perkebunan Sawit Per Kabupaten Tahun 2014

\begin{tabular}{|c|c|c|c|c|c|c|c|}
\hline \multirow[b]{2}{*}{ No } & \multirow[b]{2}{*}{ KABUPATEN } & \multicolumn{3}{|c|}{$\begin{array}{c}\text { LUAS AREAL MENURUT } \\
\text { KOMPOSISI TANAMAN (Ha) }\end{array}$} & \multirow{2}{*}{$\begin{array}{l}\text { JUMLAH } \\
\text { LUAS } \\
\text { AREAL } \\
(\mathrm{Ha})\end{array}$} & \multirow{2}{*}{$\begin{array}{c}\text { JUMLAH } \\
\text { PRODUKSI } \\
\text { (Ton/Tahun) }\end{array}$} & \multirow{2}{*}{$\begin{array}{l}\text { JUMLAH } \\
\text { PETANI } \\
(\mathrm{KK})\end{array}$} \\
\hline & & $\begin{array}{l}\text { Tanaman } \\
\text { Muda }\end{array}$ & $\begin{array}{c}\text { Tanaman } \\
\text { Menghasilkan }\end{array}$ & $\begin{array}{l}\text { Tanaman } \\
\text { Tua/Rusak }\end{array}$ & & & \\
\hline 1 & Sambas & 48,923 & 84,241 & 22,706 & 155,870 & 81,920 & 73,503 \\
\hline 2 & Bengkayang & 42,983 & 77,280 & 10,558 & 130,821 & 80,404 & 54,450 \\
\hline 3 & Landak & 91,445 & 87,583 & 3,822 & 182,850 & 105,739 & 37,634 \\
\hline 4 & Pontianak & 18,398 & 22,374 & 11,307 & 52,079 & 22,873 & 29,750 \\
\hline 5 & Sanggau & 92,471 & 245,064 & 11,663 & 349,198 & 399,983 & 100,401 \\
\hline 6 & Ketapang & 207,125 & 182,185 & 7,111 & 396,421 & 299,054 & 47,835 \\
\hline 7 & Sintang & 82,195 & 135,635 & 9,298 & 227,128 & 187,037 & 66,971 \\
\hline 8 & Kapuas Hulu & 67,263 & 53,775 & 3,526 & 124,564 & 49,544 & 34,115 \\
\hline 9 & Sekadau & 29,701 & 97,768 & 9,275 & 136,744 & 128,316 & 29,947 \\
\hline 10 & Melawi & 39,870 & 28,353 & 4,517 & 72,740 & 40,520 & 21,968 \\
\hline 11 & Kayong Utara & 20,894 & 24,123 & 1,407 & 46,424 & 27,628 & 11,955 \\
\hline 12 & Kubu Raya & 52,999 & 90,332 & 11,989 & 155,320 & 93,092 & 47,660 \\
\hline \multirow[t]{2}{*}{13} & Singkawang & 5,621 & 11,942 & 2,430 & 19,993 & 10,243 & 10,020 \\
\hline & Grand Total & 799,888 & $1,140,655$ & 109,609 & $2,050,152$ & $1,526,352$ & 566,209 \\
\hline
\end{tabular}

Sumber: Kalimantan Barat Dalam Angka, 2015 
Produksinya mencapai 1.806 .753 ton pada tahun 2013. Komoditas hasil perkebunan yang mengalami penurunan produksi diantaranya: kelapa hibrida (turun 4,00\%), karet (turun 3,03 $\%$ ), dan kelapa dalam (turun 1,79 \%) (Kalimantan Barat dalam angka, 2015).

\subsection{Profil Sumberdaya Manusia yang Dibutuhkan untuk Mendukung}

Pengembangan dan Peningkatan Industri Kelapa Sawit di Kabupaten Ketapang

\section{Menghadapi Persaingan Bebas MEA}

Berdasarkan temuan dalam penelitian ini nampak bahwa secara umum tenaga kerja atau sumberdaya manusia yang ada di Kabupaten Ketapang Provinsi Kalimantan Barat belum siap menghadapi pasa bebas MEA. Hal ini ditandai dengan rendahnya produktivitas yang salah satunya menyebabkan upah menjadi rendah, tingkat dan kualitas pendidikan yang rendah, belum memiliki kemampuan bahasa asing terutama bahasa Inggris, dan belum memiliki keterampilan atau keahlian sesuai dengan yang dibutuhkan terutama yang berkaitan dengan bidang kelapa sawit mulai dari hulu sampai ke hilir.

Beberapa upaya yang dapat dilakukan dalam menghadapi persaingan pasar bebas MEA menurut hasil temuan dalam penelitian ini adalah sebagai berikut:

1) Pemerintah Kabupaten Ketapang dapat memanfaatkan hambatan perdagangan untuk mengerem membanjirnya produk dan jasa asing.

2) Pemerintah Kabupaten Ketapang perlu menciptakan sumber daya pengusaha yang kompeten melalui pendidikan dan pelatihan.

3) Pemerintah Kabupaten Ketapang perlu membentuk forum sengketa perjanjian perdagangan bebas dengan prosedur yang sederhana dan jelas sehingga kepastian hukum.

4) Pemerintah Kabupaten Ketapang perlu melakukan perbaikan terhadap kualitas SDM tenaga kerja dalam rangka meningkatkan daya saing tenaga kerja tersebut di pasar ASEAN. Tidak hanya dari segi kemampuan pendidikan, keahlian, dan produktifitas namun yang tidak kalah penting adalah pembekalan kemampuan penguasaan bahasa asing bagi tenaga kerja, seperti sudah banyak diberitakan bahwa negara-negara di ASEAN seperti Thailand bahkan Australia sudah mengadakan pelajaran Bahasa Indonesia pada pendidikannya. Hal tersebut dapat menjadi ancaman bagi pasar tenaga kerja lokal dari serbuan tenaga kerja asing.

5) Pemerintah Kabupaten Ketapang perlu mengkaji dan menerapkan berbagai strategi yang tertuang dalam kebijakan, program-program kegiatan serta didukung 
pelaksanaan yang serius melalui kerjasama antara pemerintah, akademisi, dan dunia usaha/dunia industri yang ada di Kabupaten Ketapang sehingga dapat lebih siap dalam menghadapi MEA di tahun 2015.

6) Pemerintah Kabupaten Ketapang perlu meningkatkan pembangunan infrastrukur baik secara kuantitas maupun kualitas.

7) Pemerintah Kabupaten Ketapang memberikan kemudahan dalam memperoleh pendidikan/pelatihan bagi warga masyarakatnya.

8) Pemerintah Kabupaten Ketapang perlu melakukan sosialisasi persiapan menghadapi MEA. Sosialisasi tersebut bukan semata-mata mengenai cara menembus pasar ASEAN tetapi yang jauh lebih penting adalah bagaimana para pengusaha bisa bertahan di pasar lokal di tengah-tengah besarnya perdagangan jasa dari ASEAN, yang tentunya akan melibatkan SDM tenaga kerja yang ahli dan terampil.

9) Pemerintah Kabupaten Ketapang perlu meningkatkan upaya perlindungan tenaga. Oleh karena itu, perlu mengakui pentingnya regulasi penempatan pekerja asing yang lebih baik meskipun lapangan kerja yang membutuhkan kecakapan rendah juga masih tersedia secara luas.

10) Pemerintah Kabupaten Ketapang perlu mengambil langkah-langkah konkrit agar bisa bersaing menghadapi tenaga kerja asing dengan memperhatikan beberapa hal: Pertama, pemerintah perlu membuat undang-undang atau peraturan pokok yang berisi pengaturan secara menyeluruh dan komprehensif di bidang ketenagakerjaan. Hal inilah yang menjadi pegangan sebagai aturan main dunia ketenagakerjaan di Indonesia saat memasuki MEA. Undang-Undang ini diharapkan juga akan melindungi pekerja Indonesia. Kedua, pemerintah perlu mencari terobosan dan cara singkat untuk meningkatkan ketrampilan dan kompetensi kerja bagi SDM kita yang sesuai dengan kebutuhan pasar MEA nantinya dan bukan hanya terobosan yang sifatnya normatif melalui Peraturan perundang-undangan. Salah satu upayanya bisa dengan mengoptimalkan sarana prasarana yang ada baik dengan sering mengadakan workshop ataupun seminar bagi angkatan kerja baru maupun pelatihan peningkatan kualitas skill bagi angkatan kerja yang sudah ada. Pengenalan bahasa negara ASEAN lainnya atau minimal penguatan bahasa Internasional seperti bahasa Inggris kepada pekerja atau masyarakat kita bisa dijadikan terobosan sebagai upaya 
persiapan menghadapi MEA. Selain itu perlu adanya pelatihan bagi pekerja Indonesia untuk belajar memahami dan terus mengupdate teknologi terkini yang mendukung setiap pekerjaannya. Hal ini jelas akan meningkatkan keahlian mereka sehingga akan meningkatkan daya saing mereka dengan pekerja dari negara ASEAN lainnya. Ketiga, pemerintah wajib melaksanakan pengawasan dan penegakan peraturan perundang-undangan ketenagakerjaan. Dalam menghadapi MEA, posisi pengawas ketenagakerjaan menjadi hal yang sangat penting dalam hubungan industrial agar semakin kondusif dan sebagai pelindung bagi pekerja dalam menghadapi persaingan global ini. Upaya persiapan yang harus segera dibenahi adalah kualitas dan kuantitas tenaga pengawas ketenagakerjaan tersebut.

\subsection{Strategi dan Kebijakan Bisnis yang Perlu Diterapkan oleh Industri Kelapa Sawit di Kabupaten Ketapang Menghadapi Pasar Bebas MEA}

Strategi dan kebijakan dalam bisnis sangatlah diperlukan untuk keberlangsungan bisnis itu sendiri terutama bagi bisnis perusahan. Untuk mencapai sebuah strategi yang telah ditetapkan oleh perusahaan dalam rangka mempunyai keunggulan kompetitif, maka para pimpinan perusahaa dan para manajer, haruslah bekerja dalam sebuah sistem yang ada pada proses perencanaan strategis.

Terdapat enam strategi untuk menghadapi persaingan global. Pertama strategi pertumbuhan yang cepat atau pengurangan. Penambahan atau pengurangan jumlah karyawan maupun unit bisnis sambil mempertahankan bauran produk dan jangkauan pasar. Tindakan yang demikian itu akan mengubah ukuran perusahaan daripada ruang lingkupnya. Strategi kedua, yaitu, perubahan bauran produk. Bauran produk yang dirubah senantiasa berdampak pada operasi perusahaan juga strategi pemasaran dan strategi penjualan dimana penambahan produk dapat dilakukan seperti dengan akuisisi. Strategi ketiga, ialah perubahan jangkauan pasar. Fokus pasar dirubah pada bauran produk yang sama sehinmgga menjamah pasar internasional atau jangkauan geografis meluas dan menemukan konsumen sasaran yang baru. Strategi keempat tidak lain repositioning. Repositioning bertujuan mengubah persepsi konsumen dan atau calon konsumen akan perusahaan. Strategi yang kelima adalah diversifikasi. Diversifikasi dalam kenyataannya mencakup juga penambahan produk dan perluasan pasar yang berhubungan dengan bisnis inti maupun bukan bisnis inti. Dan yang keenam tidak lain strategi partnering. Kerjasama antara dua atau lebih perusahaan independent untuk menciptakan suatu keunggulan bersaing. 


\section{SIMPULAN}

Berdasarkan hasil penelitian yang dilakukan, disimpulkan bahwa Sumberdaya manusia yang dibutuhkan untuk mendukung pengembangan dan peningkatan industri kelapa sawit di Kabupaten Ketapang dalam menghadapi persaingan pasar bebas MEA adalah sumberdaya manusia yang tidak hanya memiliki kemampuan pendidikan, keahlian, dan produktivitas namun harus dibekali dengan kemampuan penguasaan bahasa asing, seperti bahasa Inggris. Strategi dan kebijakan bisnis yang perlu diterapkan oleh industri kelapa sawit di Kabupaten Ketapang dalam menghadapi persaingan pasar bebas MEA adalah: (1) strategi pertumbuhan yang cepat atau pengurangan, (2) strategi perubahan bauran produk, (3) strategi perubahan jangkauan pasar, (4) strategi repositioning, (5) strategi diversifikasi, dan (6) strategi partnering.

\section{DAFTAR PUSTAKA}

Dinas Perkebunan Ketapang, 2015.

Kalimantan Barat dalam angka, 2015.

Ketapang dalam angka, 2015.

Rosmalinda., dan A. Susanto. 2018. Aplikasi Limbah Cair Pabrik Kelapa Sawit Dalam Memperbaiki Sifat Kimia Tanah Gambut'. Jurnal Teknologi Agro Industri, EISSN 2598-5885, P-ISSN 2407-4624, Vol. 5 No. 2, Hal. 58.

Susanto, A dan Akhdiyatul. 2017. Rancang Bangun Alat Dan Aplikasinya Dengan Pengaruh Suhu dan Waktu Proses Pada Food Grade Grase Berbasis Minyal Sawit Crude Palm Oil (CPO) Skala Kecil. Jurnal Cyber-Techn. Vol 11 No 02 $: 1-6$.

Susanto, A., Tri. Y. 2013. Pembuatan Briket Bioarang Dari Cangkang dan Tandan Kosong Sawit. Jurnal Teknologi Hasil Pertanian, Vol. VI, No.2.

Totok , M., A. Susanto dan I. Pratiwi. 2017. Food Grade Grease Berbahan Baku Minyak Sawit Crude Palm Oil (CPO) Off Grade Dengan Variasi Konsentrasi Thickening. Jurnal Media Ilmiah Teknologi Pagan. Vol.4 No.1, 24-34 ISSN : 2477-2739. 